\title{
Thinking politically: Essays in political theory
}

\author{
Michael Walzer (collected by David Miller) \\ Yale University Press, New Haven and London, 2007, xxi $+337 p p ., £ 18.99$, \\ ISBN: 978-0300118162
}

Contemporary Political Theory (2009) 8, 240-242. doi:10.1057/cpt.2008.53

This is a valuable collection of essays. Michael Walzer is one of the most important contemporary political theorists, but his major book-length studies of general interest date from a generation ago - Just and Unjust Wars (1977) and Spheres of Justice (1983). Since then he has produced a series of short monographs, several based on his prestigious lecture series, but his main focus has been on the specialized field of Jewish political thought and traditions, and his contributions to the wider discourse have been in the form of scholarly papers and chapters, as well as many op-ed pieces in Dissent, the democratic socialist journal that he co-edits. The best of his papers on war were collected in Arguing About War (2004), and David Miller has now pulled together a further 18 essays on political theory more generally - though there is still a substantial international component to these papers, with important essays on humanitarian intervention and the War on Terror. One of these papers is published here for the first time, and also reproduced is the very revelatory interview Walzer gave to the online journal Imprints in 2003. As well, a bibliography of Walzer's writings is provided.

Why is Walzer an important theorist? The key to his appeal for this reviewer was provided, inadvertently, by Jon Elster when he referred to Walzer as a 'phenomenologist of the moral life' (Elster, 1992, p. 14). This was intended to be mildly disparaging, to suggest that Walzer is not a real political philosopher, someone who digs deep to get to the truth, but rather a thinker who is satisfied with working on surface phenomena, exploring moral dilemmas when and where they appear. Turn the implicit minus here into a plus and you have the key to Walzer's appeal. Running through these essays is a rejection of liberal political philosophy in favour of liberal (in a European context, social democratic) political theory - Walzer has little time for abstract constructs such as Rawls's 'original position' or Habermas's 'ideal speech situation', or for the hypothetical examples beloved of authors favoured by journals such as Philosophy and Public Affairs. Attempts to resolve political arguments via the production of philosophical truths are, he would argue, not simply doomed to fail, they are positively harmful because they draw attention and brainpower away from the real political problems and 
foster an anti-democratic frame of mind; ever more elaborate investigations into the hypothetical problems of an egalitarian society should be no substitute for political engagement devoted to attacking current inequalities and injustices. The findings of philosophers should not be substituted for the outcomes of democratic politics.

What all this means in practice for Walzer is a very social democratic version of liberalism. He is firmly situated within both the anti-communist American left - a proud tradition to which many of the Company of Critics, such as C. Wright Mills and Michael Harrington, belong (Walzer, 1988) - and the socialist wing of the Zionist movement in the United States. This is a location that confuses many European critics, who pick up on Walzer's Zionism without recognizing that his radical commitments lead him to condemn many Israeli policies, while wholeheartedly defending the right of Israel to exist. Similarly, his nuanced response to $9 / 11$ - no blank cheque for the Bush administration but a willingness to support them when they did the right thing - was not appreciated by those who see the world in black and white, but was wholly consistent with the approach he has taken throughout his career. His classic essay on 'Dirty Hands' (the only pre-1980 essay included in this collection) contains more wisdom on the War on Terror and the debates on torture than any other 17 pages I know.

The Zionist and the explicitly American dimensions of Walzer's work makes him particularly sensitive to issues of nationality, identity and multiculturalism (all topics discussed brilliantly in this collection), but his democratic socialism ensures that he leaves some room for universal values; his account of when humanitarian intervention in defence of basic human rights is legitimate, even possibly obligatory, is simply masterly. At the heart of his political theory are real people living real lives, and, ultimately, abstractions such as the nation have to take second place to this reality; by the same token his socialism makes him willing to countenance stateaction at a level that would offend many liberals, but always contained within the appropriate sphere and never at the expense of human individuality.

Each one of these essays merits re-reading, and some are of seminal importance. Moreover - and here is another difference between Walzer and many contemporary political philosophers - they are a joy to read. He is one of the great modern political writers, up there with George Orwell and very few others. In this collection David Miller has chosen well, and his introduction is brief, lucid and helpful. One very minor gripe; it would have been good to have had the date of these essays noted somewhere in the body of each work or the table of contents - the information is there but only in the list of published works. A point for the paperback perhaps? 


\title{
References
}

Elster, J. (1992) Local Justice. New York: Russell Sage Foundation. Walzer, M. (1977) Just and Unjust Wars. New York: Basic Books. Walzer, M. (1983) Spheres of Justice. New York: Basic Books. Walzer, M. (1988) The Company of Critics. New York: Basic Books. Walzer, M. (2004) Arguing About War. New Haven, CT: Yale University Press.

Chris Brown London School of Economics, London, UK

\section{Anarchism and authority: A philosophical introduction to classical anarchism}

\author{
Paul McLaughlin \\ Ashgate Publishing, Aldershot, 2007, 202pp., £55.00, ISBN: 978-0754661962
}

Contemporary Political Theory (2009) 8, 242-244. doi:10.1057/cpt.2008.54

McLaughlin's aim in this book is to re-define the relationship between anarchism and authority and correct what he believes is a misapprehension: that anarchism can be defined in terms of a rejection of the state or of authority 'as such'. Indeed, in the course of the book he argues that anarchists accept quite a lot of authority. For example, they typically accept parental authority and what he calls operative authority.

The book is organized in two parts. Thus the argument is not a philosophical analysis of the concept in classical anarchism, as the title implies. Rather it is first, an account of the concept of authority and second, an analysis of authority in three leading classical theorists: Godwin, Proudhon and Stirner.

The conceptual analysis is wide-ranging and premised on the notion of scepticism. Anarchist scepticism differs from other kinds (Pyrrhonian and Cartesian) because it is not used as a devise for revelation or the discovery of truth and because it is political or ethical rather than personalistic. Yet the important point, here, seems to be to provide a springboard for an analysis which relies heavily on liberal theory, principally critical liberalism of Joseph Raz and Leslie Green. It's not surprising, therefore, to find that McLaughlin finds that his treatment of anarchism might look like "no more than a radicalisation of liberalism' (p. 53). He denies that anarchism can in fact be represented in this way, but his approach undoubtedly encourages such a view. 